VOX PATRUM 24 (2004) t. 46-47

Ks. Jarosław WOCH

(Częstochowa, WSD)

\title{
BISKUP RZYMU WOBEC PROBLEMÓW KOSCIOŁÓW WSCHODNICH PRZY KOŃCU IV WIEKU
}

Na podstawie dekretałów papieża Syrycjusza (384-399), pierwszych o niekwestionowanym autorstwie zachowanych dokumentach papieskich ${ }^{1}$, można dostrzec, iż władza Stolicy Apostolskiej, w tym okresie obejmowała swym zasięgiem przede wszystkim Kościoły Zachodu, szczególnie należące do rzymskiej metropolii ${ }^{2}$. Na chrześcijańskim Wschodzie rola biskupa Rzymu

${ }^{1}$ Opublikowany przez J.P. Migne'a Corpus Siricii zawiera 10 listów (S. Siricii papae Epistolae et Decreta, PL 13,1131-1196), nie wszystkie jednak są autorstwa Syrycjusza. Zagadnienie autorstwa tych listow do dzisiaj budzi zainteresowanie uczonych. Jednym z nich był Charles Babut, który na początku ubieglego stulecia opublikowal swoją pracę doktorską, przedstawioną na Wydziale Literatury Uniwersytetu w Paryżu, pod tytułem La plus ancienne décrétale, Paris 1904. Tytuł pracy i jej treść odnoszą się do dekretału Dominus inter, znanego również jako Canones ad Gallos (czy Ad Gallos Episcopos), zamieszczonego już przez P. Coustanta w zbiorze listów Syrycjusza (Epistulae Romanorum Pontificum, t. 1, Paris 1721, 624-1006). Według Babuta autorem tego dekretału był papież Damazy. Teza ta zostala przyjęta przez współczesnych uczonych, por. Patrologia, red. A. di Berardino, III, Casale 1983, 263. Trzeba jednak zaznaczyć, że są również uczeni, negujący tezę Babuta: „E.Ch. Babut hat in seiner pariser These La plus ancienne décrétale versucht für die Canones ad Gallos episcopos Damasus als Verfasser nachzuweisen, nach meinem Dafürhalten ohne stichhaltige Gründe (H. Getzeny, Stil und Form der ältesten Papstbriefe bis auf Leo den Großen, Günzburg 1922, 94); „als «älteste päpstliche Dekretale» wird Siricius' großes Schreiben an den Bischof Himerius von Tarragona vom Februar 385 (JK 255) gelten müssen" (D. Jasper, Die Canones synodi Romanorum ad Gallos episcopos: Die älteste Dekretale?, ZKG 107:1996, 326).

${ }^{2} \mathrm{Na}$ pięć dekretałów Syrycjusza (o niekwestionowanym autorstwie) trzy są adresowane do diecezji zachodnich: dekretal Directa ad decessorem z 10 lutego 385 r., skierowany do metropolity Tarragony (dzisiejsza Hiszpania) i diecezji sąsiednich; list synodalny Cum in unum z 6 stycznia 386 r., adresowany do biskupów diecezji przynależących do jurysdykcji papieskiej, przesłany także do Kościołów afrykańskich; list Optarem semper, podejmujący kwestię Jowiniana rozpatrywaną na synodzie rzymskim (390), adresowany do Ambrożego, biskupa Mediolanu. Pontyfikat papieża Syrycjusza był przedmiotem pracy doktorskiej autora artykułu, przedstawionej w 1999 r. w Instytucie Patrystycznym „Augustinianum" w Rzymie. Z badań wówczas przeprowadzonych wynika, że Syrycjuszowi można przypisać z całkowitą pewnością pięć listów: Directa ad decessorem, Etiam dudum, Cum in unum, Cogitantibus nobis, Optarem semper, por. J. Woch, „Portamus onera omnium qui gravantur [...]". Il pontificato di papa Siricio (384-399) alla luce dei suoi scritti e delle fonti archeologiche, Roma 1999, 195 (mps). 
postrzegana była raczej w relacji do polityki cesarskiej ${ }^{3}$. Potraktowanie przez sobór w Konstantynopolu (381) tegoż miasta jako nowego Rzymu ${ }^{4}$ miało za cel odnowienie Kościoła, targanego przez liczne herezje, w duchu ortodoksyjnej nauki Soboru Nicejskiego, strzeżonego przez swojego cesarza ${ }^{5}$. Interesujące będzie więc prześledzenie relacji, jaka zachodziła między rzymskim biskupstwem, a Kościołami Wschodu za pontyfikatu papieża Syrycjusza, którego „zadaniem była troska o wszystkie Kościoły” (cui ecclesiarum omnium cura est) ${ }^{6}$.

\section{ROZWIAZZANIE SCHIZMY ANTIOCHEŃSKIEJ}

Jednym z ważniejszych centrów chrześcijaństwa IV wieku była Antiochia, stolica Syrii: stosunkowo wcześnie stała się chrześcijańska. Po prześladowaniach za Dioklecjana i Licyniusza cieszyła się życzliwością cesarza Konstantyna, czego wyrazem może być wspaniała bazylika przez niego tam zbudowana ${ }^{7}$. Szybko osiągnęła swe znaczenie, stając się jedną z najważniejszych stolic kościelnych IV wieku ${ }^{8}$. Zanim Sobór Konstantynopolitański postanowił, że „biskup Konstantynopola powinien mieć honorowe pierwszeństwo po biskupie Rzymu", , szczególna pozycja kościelna Antiochii wynikała bardziej z jej apostolskiego pochodzenia (św. Piotr), niż z jej politycznego znaczenia w imperium $^{10}$. U początków $V$ wieku jej biskup konsekrował wszystkich metropoli-

${ }^{3}$ Przypomnijmy, że dla chrześcijan Wschodu Rzym był jedną ze stolic apostolskich, czyli zalożonych przez Apostołów.

${ }^{4}$ Por. Concilium Constantinopolitanum I, can. 3, w: Dokumenty Soborów Powszechnych. Tekst grecki, tacinski, polski, t. 1: (325-787), red. A. Baron - H. Pietras, ZMT 24, Kraków 2001 (= DSP I) 72-73.

${ }^{5}$ Por. tamże, can. 1, DSP I 70-71; Ch. Pietri, Roma Christiana. Recherches sur l'Église de Rome, son organisation, sa politique, son idéologie de Miltiade à Sixte (311-440), t. 1, Rome 1976, 856-860. W brzmieniu tego kanonu konkurowały ze sobą różne tendencje, jednak według historyków ta decyzja nie miała na celu sprzeciwianie się władzy biskupa Rzymu, której fundament Piotrowy był niepodważalny. Bardziej ujawnia się tu intencja zapewnienia dominacji stolicy konstantynopolitańskiej nad pozostałymi patriarchatami Wschodu: Jerozolimą, Aleksandrią i Antiochią, jak również nadanie stolicy cesarstwa najwyższej pozycji, zob. Storia della Chiesa, red. H. Jedin, t. 2: Epoca dei concili, tłum. wi., Milano 1992, 81-82.

6 Por. Siricius, Epistula 6 („Cogitantibus nobis”) 1, 1, PL 13, 1164A.

${ }^{7}$ Por. Storia della Chiesa, dz. cyt., s. 205.

${ }^{8}$ Por, tamże, s. 81-82.

9 Concilium Constantinopolitanum, can. 3, DSP 173 ; por. G. Alberigo, Concilium Oecumenicorum Decreta, Bologna 1991, 28.

${ }^{10} \mathrm{O}$ Antiochii w następujących słowach pisal św. Hieronim: „ut Palaestinae metropolis Caesaria sit, et totius Orientis Antiochia" (Contra loannem Hierosolymitanum 37, PL 23, 389C). Współcześni historycy ów „prymat” antiocheński charakteryzują raczej jako tytuł honorowy, por. P. Batiffol, La paix constantinienne et le catholicisme, Paris 1914², 131-132. 
tów. Taki autorytet mógłby się dalej rozwijać, gdyby nie pewne wydarzenia, które doprowadziły do jego osłabienia i ograniczenia ${ }^{11}$.

Kościół antiocheński był pod koniec IV wieku równocześnie nicejski i melecjański. W 387 r. rezydowało w nim dwóch ortodoksyjnych biskupów: Flawian, który od 381 r. zastąpił Melecjusza oraz Paulin, zwolennik Eustachiusza, wybrany w 362 roku. Ten ostatni, rywal Melecjusza, dwukrotnie zostal uznany przez Rzym (375 i 382) za prawowitego biskupa Antiochii ${ }^{12}$. Tuż przed swoją śmiercią, która nastąpiła w 388 r., Paulin desygnował jako swego następcę kapłana Ewagriusza, dokonując jednak sam jego święceń i nie respektując $w$ ten sposób obowiązującej dyscypliny kościelnej ${ }^{13}$. Biskupi Zachodu, jak i Egiptu, udzielili poparcia Ewagriuszowi, który został uznany za biskupa Antiochii ${ }^{14}$. Biskupi Illyricum zaś poparli Flawiana, któremu Rzym nie udzielił komunii ${ }^{15}$.

1. Synod w Kapui. Tego rodzaju sytuacja sprzyjała podziałom między Wschodem a Zachodem. Cesarz Teodozjusz przebywał w latach 388-391 w Italii, aby wzmocnić tam panowanie młodego Walentyniana. Po powrocie do Konstantynopola, który nastąpił między 14 lipca a 10 listopada $391 \mathbf{r}^{16}$, cesarz zdecydował się położyć kres konfliktowi, który trwal już ponad dziesięć lat. Niektórzy badacze przypuszczają, że Teodozjusz, podczas swego pobytu w Italii, zostal nawet proszony przez Syrycjusza o rozwiązanie schizmy antiocheńskiej wpływając na ustąpienie Flawiana ${ }^{17}$. S. de Tillemont i J.R. Palanque $z$ kolei widzą tu inicjatywę samego cesarza, który zaproponował, aby spór antiocheński został podporządkowany osądowi Kościoła rzymskiego ${ }^{18}$. W od-

${ }^{11}$ Por. Storia della Chiesa. Dalle origini ai giorni nostri, red. A. Fliche - V. Martin, III/2, tłum. wi., Torino $1972^{3}, 659-660$.

12 Por. M. Simonetti, Melezio di Antiochia, DPAC II 2205-2206; także E. Soler, Evêque et pasteurs à Antioche sous l'empereur Théodose: l'engagement chrétien dans la défense de la cité apreé la sédition des statues (387), w : Vescovi e Pastori in epoca teodosiana. In occasione del XVI centenario della consacrazione episcopale di S. Agostino 396-1996 (XXV Incontro di studiosi dell'antichità cristiana, Roma, 8-11 maggio 1996), Roma 1997, 462.

${ }^{13}$ Concilium Nicaenum, can. 4, DSP I 29. Tę dyscyplinę potwierdza również papież Syrycjusz: „Ne unus episcopus episcopum ordinare praesumat propter adrogantiam, ne furtivum beneficium praestitum videatur; hoc enim in synodo Nicaena constat esse definitum" (Epistola 5 [„Cum in unum"]) 2, CCL 149, 61; PL 13, 1157-1158.

14 Por. Theodoretus, HE V 23, PG 82, 1247-1250.

15 Por. Pietri, Roma Christiana, dz. cyt., t. 2, s. 1077.

${ }^{16}$ Odnośnie do tej daty zob. O. Seeck, Regesten der Kaiser und Päpste für Jahre 311 bis $476 n$. Chr. Vorarbeitet zu einer Prosopographie der christlichen Kaiserzeit, Stuttgart 1919, 279.

17 Według Solera Teodozjusz, podczas swego pobytu w Italii, został poproszony przez papieża Syrycjusza o rozwiązanie schizmy antiocheńskiej, por. E. Soler, Evêque et pasteurs, art. cyt., s. 466-467.

18 Por. J.R. Palanque, Saint'Ambroise et l'empire romain. Contribution a l'histoire des rapports de l'Église et de l'Etat à la fin du quatrieme siècle, Paris 1933, 255; S. Le Nain de Tillemont, Mémoires pour servir à l'histoire ecclésiastique des six premiers siècles, t. 10, Venise 1732, 234. Także A. Iodice suponuje, że Teodozjusz przebywając w Rzymie słyszał skargi papieża Syrycjusza 
powiedzi na cesarskie pragnienie został zwołany synod rzymski w Kapui ${ }^{19}$, co do którego mogą się zrodzić następujące pytania:

- najpierw dlaczego wybrano właśnie to miejsce, a nie sam Rzym? Wedlug J.R. Palanque, wspomnianego już znawcy św. Ambrożego, całe to wydarzenie należy umieścić w kontekście dominacji w polityce kościelnej i świeckiej biskupa Mediolanu. W tej sytuacji papież Syrycjusz nie musiał przejawiać chęci do przejęcia inicjatywy, obawiając się znaczącej aktywności Ambrożego oraz własnej pasywności, podobnie jak to miało miejsce podczas synodu w Akwilei (381), któremu tenże biskup przewodniczył: Syrycjusz zadecydował więc, aby „rzymskie" zgromadzenie biskupów odbyło się w Kampanii, niedaleko Rzymu ${ }^{20}$.

przeciwko Flawianowi, którego wybór na stolicę biskupią w Antiochii zainicjowal schizmę, por. A. Jodice, Il contesto storico del concilio di Capua (391-392) e la sua memoria nella storiografia ecclesiastica, w: XVI Centenario del concilio di Capua (392-1992). Atti del Convegno internazionale di studi mariologici (Capua 19-24 maggio 1992), red. G. Liccardo, Capua - Roma 1993, 57.

${ }^{19}$ Por. Ch.J. Hefele, Histoire des Conciles, II/1, Paris 1908, 80-82.

${ }^{20}$ Por. Palanque, Saint Ambroise et l'empire romain, s. 255-256. Zaznaczmy, że interesujące zagadnienie relacji między Ambrożym z Mediolanu a Syrycjuszem z Rzymu, jaka musiała zaistnieć na plaszczyźnie polityki kościelnej, nie jest glównym przedmiotem niniejszego studium. Analiza tego zagadnienia, w szerokim kontekście, z pewnością, rzucilaby wiele światła na ukazanie roli biskupa Rzymu przy końcu IV wieku. Niewątpliwie, Ambroży w tym okresie był dominującą postacią tak w kręgach ogólnokościelnych jak i w cesarstwie. Pomimo sarkastycznych wypowiedzi na temat następcy Damazego, tak ze strony Hieronima (,simplicitas" nowego biskupa, por. Epistula 127, 9, CSEL 56, 152, 20-26) jak i Paulina z Noli (,superba discretio urbici papae”, por. Epistula 5, 14, CSEL 29, 33, 1-3), naznaczonych osobistymi animozjami (zob. N. Adkin, Pope Siricius' „Simplicity”: Jerome, Epist. 127, 9, 3, VetChr 33:1996, 25-28) odkrywa się w nich „ziamo prawdy, kiedy Syrycjusz zostaje skonfrontowany z postacią ówczesnego biskupa Mediolanu, Ambrożego. W jego ręce, a nie do Rzymu, biegną nici wielkiej polityki Kościoła; Ambroży koresponduje $\mathrm{z}$ biskupami Wschodu, zwołuje ważne synody międzyregionalne, jest decydującym rozmówcą cesarzy i cesarskiej administracji: aktywność Syrycjusza pozostaje natomiast ograniczona do wewnątrz Kościoła łacińskiego i kroczy według głównych kierunków, które się rozwinęły za czasów Damazego", por. Storia della Chiesa, dz. cyt., s. 278). To, iż Syrycjusz mial niełatwe zadanie w konfrontacji z Ambrożym, zauważa również A. Tuilier: „Sous son pontificat (to znaczy Syrycjusza - przyp. autora) d'ailleurs, l'autorité de la papauté romaine est concurrencée par la personnalité exceptionelle de saint Ambroise, qui occupe le siège épiscopale de Milan entre 373 et 397. A l'instar de Damase et de Sirice, Ambroise est issu d'une grande famille aristocratique romaine. [...] Ambroise était toutefois différent de Damase et de Sirice dans la mesure où il appartenait à la haute administration impériale et où il était gouverneur de la province de Ligurie et d'Emilie, dont Milan était capitale, lorsqu'il devint l'évêque de cette ville" (La politique de Theodose le Grand et les eveques de la fin du $I^{k^{m}}$ siecle, w: Vescovi e Pastori in epoca teodosiana, dz. cyt., s. 61). W odpowiedzi na zagadnienie korespondencji Ambrożego z innymi biskupami, o której wspomnieli Baus i Ewig, redaktorzy II tomu Storia della Chiesa, H. Jedin i M. Zelzer, wydawca listów św. Ambrożego „extra collectionem” zauważa, że w IV wieku, podobnie jak i dzisiaj, wymiana korespondencji była wyrazem przyjaźni. Tej tradycji był wierny św. Ambroży, co potwierdzaja jego listy. „Secondo me - pisze - ci si può fare un'idea del rapporto fra Ambrogio e Siricio: egli non lo considerava un suo amico, gli rende però un grande onore con la dedica di due lettere (podkreslenie autora). Solo un'altra volta Ambrogio si riferisce a Siricio nella sua raccolta epistolare, ma senza nominarlo: tra le lettere politico religiose si trova una risposta ad una lettera del vescovo 
- kolejne pytanie dotyczy osoby Syrycjusza. Nie posiadamy żadnej pewnej informacji o obecności biskupa Rzymu na tym synodzie. De Tillemont cytuje Blondela, który twierdzi, że Syrycjusz i Ambroży przewodniczyli temu synodowi ${ }^{21}$. Jest oczywiste, że obaj hierarchowie byli bardzo zainteresowani tą kwestią, jednakże co do faktycznej obecności Syrycjusza na tym synodzie, brak wystarczających potwierdzeń w źródłach. Jest natomiast prawdopodobne, iż papiez, nie uczestnicząc osobiście w synodzie, wysłał tam swoich legatów, według zwyczaju ówczesnych biskupów rzymskich, którzy nigdy nie opuszczali swojej siedziby ${ }^{22}$. Podejmując temat osoby przewodniczącej na tym synodzie A. Iodice wyraża przekonanie, iż był to prawdopodobnie Ambroży z Mediolanu. Przypuszcza on również, że sam Syrycjusz zlecił mu to przewodniczenie, jak i reprezentację Stolicy Apostolskiej ${ }^{23}$. Należy zauważyć, że teza ta nie jest pozbawiona racji, gdyż papież Syrycjusz kontaktował się już w przeszłości z biskupem Mediolanu w sprawie herezji Jowiniana, heretyka, potępionego przez synod rzymski w 390 roku $^{24}$.

Teofilo di Alessandria, nella quale questi si lamenta della durata dello scisma antiocheno. Ambrogio, avendo capito che il vescovo desiderato da lui e da Teofilo non sarebbe stato vincitore gli propose, da politico intelligente qual era, di rivolgersi in tale faccenda uad sanctum fratrem nostrum, Romanae sacerdotem ecclesiae»" (podkreślenie autora; dodajmy, że pisząc te słowa Ambroży myśli o Syrycjuszu...)", por. M. Zelzer, Vescovi e pastori alla luce delle lettere ambrosiane, w: Vescovi e Pastori in epoca teodosiana, dz. cyt, s. 562-563. Jak więc widać, nie można zgodzić się łatwo z tezą, iż Syrycjusz był postacią całkiem wyblakłą wobec biskupa Ambrożego. M. Zelzer wskazuje również na dwa inne, krótkie listy Ambrożego, skierowane do Syrycjusza, które świadczą o szacunku, jakim Ambroży darzyl następcę sw. Piotra, zob. Epistula 41 [Maur. 86], w: Sancti Ambrosii episcopi Mediolanensis Opera (=SAEMO). Tutte le opere di sant'Ambrogio. Edizione bilingue a cura della Biblioteca Ambrosiana, t. 20, Milano-Roma 1977, 64; Epistula 46 [Maur. 85], tamże, s. 72; por. M. Zelzer, Zur Chronologie der Werke des Ambrosius. Úberblick über die Forschung von 1974 bis 1997, w: „Nec timeo mori”. Atti del Congresso internazionale di studi ambrosiani nel XVI centenario della morte di sant'Ambrogio (Milano, 4-11 Aprile 1997), red. L.F. Pizzolato - M. Rizzi, Milano 1998, 84, przypis 57. Na temat relacji między Stolicą Apostolską $\mathrm{i}$ jej biskupem, a biskupem Mediolanu następujące słowa notuje biograf sw. Ambrożego: „La modération des papes Damase et Sirice, respecteux d'un pontifie si populaire et si influent, empêcha tout conflit d'éclater entre Rome et Milan; mais c'est le prestige de sa personne, non l'éclat de son siège, qui lui assura, dans les relationes ecclésiastiques, une place prépondérante" (Palanque, Saint Ambroise, dz. cyt., s. 398-399). Możemy więc przypuszczać, iż wycofanie się Syrycjusza, na niejako drugi plan sceny polityki kościelnej względem Ambrożego, może świadczyć o wytrawności politycznej papieża, który nie tyle dbal o osobiste znaczenie, ile bardziej o stabilność i jedność Kościoła sobie powierzonego.

${ }^{21}$ Por. D. Blondel, De la primauté en l'Église, Geneve 1641, 237 (cyt. za: S. Le Nain de Tillemont, Mémoires pour servir, t. 10, s. 236).

22 Por. Le Nain de Tillemont, Mémoires pour servir, t. 10, s. 236.

23 Por. Iodice, 1 ll contesto storico del concilio di Capua (391-392), art. cyt., s. 58 i 60: „Al concilio di Capua prese parte Ambrogio, vescovo di Milano. Molto probabilmente lo inviò a Capua come presidente e delegato il papa Siricio".

${ }^{24}$ Listem Optarem semper Syrycjusz powiadamial Ambrożego o niebezpieczeństwie herezji, jaką propagowali trzej kapłani Krescencjusz, Leopard i Aleksander. Ambroży odpowiada Syry- 
Z synodu w Kapui (391-392), który miał rozwiązać kryzys antiocheński, nie zachował się żaden jego dokument. Wyjątek stanowi kanon zamieszczony w Codex canonum Ecclesiae Africanae, dotyczący dyscypliny chrzcielnej oraz wyboru i przenoszenia biskupów ${ }^{25}$. Mimo to, w oczach historyków, to wydarzenie kościelne, miało duże znaczenie i jest uważane za synod generalny $\mathrm{Zachodu}^{26}$. Ze Wschodu nie przyjechał żaden przedstawiciel, nawet Flawian, przeciwnik Ewagriusza, choć został wezwany przez samego cesarza Teodozjusza $^{27}$. Taka postawa mogłaby świadczyć o niezadowoleniu i proteście biskupów Wschodu przeciw rozwiązywaniu ich spraw w Italii przez biskupów Zachodu ${ }^{28}$.

2. List św. Ambrożego do Teofila biskupa Aleksandrii. W zbiorach zawierających korespondencję św. Ambrożego znajduje się list posynodalny biskupa Mediolanu adresowany do biskupa Aleksandrii, Teofila ${ }^{29}$. $Z$ listu tego wynika, iż synod w Kapui zapewnił wreszcie wszystkim, którzy wyznają wiarę katolicką na całym Wschodzie, ,spokojny port”, czyli wspólnotę kościelną. Dwaj protagoniści sporu, Ewagriusz i Flawian, zostali podporządkowani jurysdykcji biskupa Aleksandrii i episkopatu egipskiego, ułatwiając w ten sposób uczestnictwo stron konfliktu w jego rozwiązaniu ${ }^{30}$. Ten sam jednak list wskazuje na to, że Flawian nie podporządkował się decyzjom synodu w Kapui, to znaczy nie chciał poddać się pod osąd biskupa Aleksandrii, odwołując się do cesarza ${ }^{31}$. Teofil, któremu powierzono realizację postanowień synodu, zwrócił się z prośbą o pomoc do Ambrożego. Ten $z$ kolei $w$ odpowiedzi poprosił go, by tak wpłynął na Flawiana, aby ten podporządkował się decyzjom soboru w Nicei i decyzjom dyscyplinarnym synodu w Kapui ${ }^{32}$.

Interesująca, z punktu widzenia naszego tematu, jest wzmianka w owym liście, która wskazuje na pewnego rodzaju „obecność” w podejmowanych decyzjach papieża Syrycjusza. W zakończeniu Ambroży odnosi się „ad sanctum

cjuszowi listem Recognovimus, gdzie zawiera krótkie exposé błędów Jowiniana oraz jego uczniów, któremu przeciwstawia prawowierną naukę, potwierdzając potępienie herezji, przez synod rzymski. W liście tym Syrycjusz zostaje nazwany przez Ambrożego „mistrzem i nauczycielem”, który tymi słowami pochwala papieża, dziękując mu za gorliwość w zwalczaniu herezji, por. Ambrosius, Epistula extra collectionem 15: „Recognovimus” (Maur. Epist. 42), 1, CSEL 82, 3, 302; Pietri, Roma Christiana, t. 2, dz. cyt., s. 1078.

25 Por. Codex canonum Ecclesiae Africanae 48, w: Mansi III 737-740.

${ }^{26}$ Por. Palanque, Saint Ambroise, dz. cyt., s. 256; Le Nain de Tillemont, Mémoires pour servir, t. 10 , s. 235 .

${ }^{27}$ Por. Theodoretus, HE V 23, PG 82, 1247-1250; F. Trisoglio, Sant'Ambrogio e Massimo il Cinico, w: „Nec timeo mori”, dz. cyt., s. 792.

28 Por. Palanque, Saint Ambroise, dz. cyt., s. 257.

29 Por. Ambrosius, Epistula 70 (Maur. 56), CSEL 82/ 3, 3-6.

30 Por. tamże, 4.

31 Por. Trisoglio, Sant'Ambrogio e Massimo il Cinico, art. cyt., s. 792.

32 Por. Ambrosius, Epistula 70 (Maur. 56), 6, CSEL 82/3, 5-6. 
fratrem nostrum, Romanae sacerdotem Ecclesiae", którego uważa za słuszne powiadomić o całej tej sprawie (sane referendum arbitramur) ${ }^{33}$. Te słowa wskazują na biskupa Rzymu ${ }^{34}$. Badacze zagadnienia są zgodni co do tego, ze „gest” biskupa Mediolanu wyraża tu raczej grzeczność w stosunku do biskupa Rzymu $^{35}$. W świetle tych komentarzy można wnioskować, że Syrycjusz, pełniąc swoją władzę na Stolicy Apostolskiej, nie miał decydującego głosu w rozwiązaniu kwestii antiocheńskiej. Potwierdzeniem tego staje się fakt, iż biskup Aleksandrii, w trudnej dla siebie sytuacji, przed jaką został postawiony, tj. w momencie, kiedy Flawian odwołuje się do cesarza, nie zwraca się bezpośrednio do biskupa Rzymu, jak to uczynił w 384 roku biskup Tarragony Himeriusz, pisząc do papieża Damazego ${ }^{36}$, ale prosi o pomoc Ambrożego. W sytuacji, gdy wzrasta świadomość prymatu papiestwa zastanawia ten fakt proszenia o protekcję nie biskupa Rzymu, ale Ambrożego. W przypadku papieża Damazego, mogłoby chodzić o jego niewątpliwy autorytet osobisty. Być może Syrycjusz, jego następca, nie cieszył się $\mathrm{w}$ równej mierze taką samą estymą wśród kolegium biskupów. Rodzi się więc pytanie o rzeczywisty autorytet biskupa Rzymu, jako następcy św. Piotra, nie będący w powiązaniu z osobistą powagą. Czy autorytet papieża, przy końcu IV wieku, był bardziej związany z osobą wypelniającą ten urząd, czy też z samym urzędem? Niektórzy ze współczesnych badaczy papiestwa określają osobowość Syrycjusza, jako wyblakłą ${ }^{37}$. Stąd można wnioskować, że w tym czasie, nie sam prestiż urzędu, ale silna osobowość papieża wpływałaby na decyzję powierzenia losów wspólnot kościelnych poza Rzymem jego arbitrażowi.

3. List Sewera $z$ Antiochii. Ferdynand Cavallerra analizując kryzys antiocheński wydobył na światło dzienne list Sewera z Antiochii (488-538), w którym

${ }^{33}$ Por. tamże, 6: „Sane referendum arbitramur ad sanctum fratrem nostrum, Romanae sacerdotem ecclesiae, quoniam praesumimus ea te iudicaturum, quae etiam illi displicere non queant. Ita enim utile erit consultum sententiae, ita pacis et quietis securitas, si id vestro statuatur consilio, quod communioni nostrae dissensionem non afferat, ut nos quoque accepta vestrorum serie statutorum, cum id gestum esse cognoverimus quod ecclesia Romana haud dubie comprobaverit, laeti fructum huiusmodi examinis adipiscamur".

${ }^{34}$ Por. Zelzer, Zur Chronologie der Werke des Ambrosius, art. cyt., s. 262-263.

${ }^{35}$ Por. Palanque, Saint Ambroise, dz. cyt., s. 258-259; M. Zelzer, CSEL 82/3, s. XXX-XXXI.

${ }^{36} \mathrm{Na}$ kwestionariusz Himeriusza, biskupa hiszpańskiej Tarragony, Damazy nie mógl już odpowiedzieć. Czyni to Syrycjusz w dekretale Directa ad decessorem [385] (= Epistula 1, PL 13, 1132-1147). Ten dekretał jest pierwszym dokumentem papieskim, jaki zachował się $w$ zbiorze dokumentów kościelnych, równy rangą dekretom synodalnym i soborowym.

${ }^{37}$ Są jednak i tacy, którzy mają odmienne zdanie: „Fin dopo la metà del secolo IV la sede romana vanta, stando alle scarse informazioni, una successione, salvo Giulio I, di figure molto scialbe (Silvestro, Marco, ecc.); verso la fine del secolo invece emergono, pur senza grandi eccezionalità, persone più decise (Damaso, Siricio)", por. Storia della Chiesa. Dalle origini ai nostri giorni, t. 3/2: Dalla pace costantiniana alla morte di Teodosio (313-395), red. G.R. Palanque G. Bardy - P de Labriolle, Torino $1972^{3}, 707$. 
jest mowa o pewnym Izajaszu, którego wybór na biskupa dokonał się w podobnym kontekście jak ten, wiek wcześniej - Ewagriusza. W swym liście biskup syryjski odnosi się właśnie do niektórych faktów, które wtedy miały miejsce. One to rzucają nowe światło na kwestię antiocheńską i rolę, jaką w niej odegrał papież Syrycjusz. Według tego dokumentu, ówczesny biskup Rzymu, powierzył zbadanie sprawy konfliktu synodowi w Kapui. Zarządził także, aby również biskupi Wschodu przeprowadzili dokładniejsze badanie tego problemu. Oto ten tekst w naszym tłumaczeniu, $\mathrm{z}$ języka francuskiego:

„Przeczytaliśmy list naszych czcigodnych braci do naszego czcigodnego brata Teofila, oraz ten, który skierowali do nas ze Wschodu biskupi zebrani w Kapui, także i ów pobożnego Syrycjusza, biskupa Rzymu. Przede wszystkim wynika z nich, że powinniśmy czuwać nad tym, aby nie gwałcić kanonu z Nicei, który jasno stwierdza, że nie można zezwolić na konsekrację biskupią przy udziale jednego tylko biskupa. List pobożnego biskupa Syrycjusza zawierał między innymi polecenie, aby rozstrzygnąc na rzecz tylko jednego biskupa w Antiochii, tego, który został wybrany w sposób uzasadniony i kanoniczny, zgodnie z normą nicejską, która określa jasno, że konsekracja dokonana przez tylko jednego [biskupa] jest nielegalna i nie może byé zaakceptowana. W konsekwencji, przyjmując $\mathrm{z}$ radością precyzyjną doktrynę biskupa Syrycjusza, w sprawie kanonów kościelnych, jesteśmy zgodni $\mathrm{z}$ jego listem i postanowiliśmy, że należy ratyfikować go w całości; zdecydowaliśmy w sposób uzasadniony i sprawiedliwy, że znamy jedynie jednego biskupa w Antiochii, pobożnego biskupa Flawiana" ${ }^{38}$.

Ze źródeł historycznych wiadomo, że schizma antiocheńska została prawnie rozwiązana dopiero przez synod zwołany w Cezarei Palestyńskiej w 393 roku ${ }^{39}$. Ojcowie synodalni, pod nieobecność Teofila z Antiochii, który w tym czasie był zajęty likwidacją świątyń pogańskich w Egipcie i wyznaczył wcześniej przewodniczącego synodu ${ }^{40}$, przesłali na piśmie podjęte decyzje do trzech

38 Tekst cytowany za: F. Cavallera, Le schisme d'Antioche (IVe-Ve siècle), Paris 1905, 286: „Nous avons lu la lettre de nos vénérables frères à notre vénérable frère l'évêque Théphile (sic!) et celle que ils ont adressée à nous-mêmes, Orientaux, les évêques réunis à Capoue, celle aussi du religieux Sirice l'évêque de Rome. Avant tout, déclaraient-elles, nous devions veiller à ne point déroger au canon de Nicée qui affirme clairement que l'on ne peut permettre l'ordination d'un évêque par un seul autre. La lettre du religieux évêque Sirice contenait en outre une direction pour le jugement à porter, où il était dit qu'il ne devait y avoir qu'un seul évêque à Antioche, celui qui était légitimement et canoniquement élu, en conformité avec la règle de Nicée définissant clairement que l'ordination faite par un seul est illégitime et ne saurait être acceptée. En conséquence, acceptant avec joie la doctrine exacte de l'évêque Sirice, au sujet des canons ecclésiastiques, nous nous sommes conformés à sa lettre et avons déclaré qu'il fallait ratifier tout cela; nous avons décidé légitimement et justement que nous ne connaisson qu'un évêque à Antioche, le religieux évêque Flavien".

${ }^{39}$ Por. A.J. Festugière, Antioche païenne et chrétienne. Libanius, Chrysostome et les moines de Syrie, Paris 1959, 257; Concilium Constantinopolitanum (393), Mansi III 851-854.

${ }^{40}$ Por. F. Cavallera, Le schisme d'Antioche (IV $-V^{e}$ siècle), dz. cyt., s. 286. 
augustów: Teodozjusza i jego synów. Tekst tego właśnie pisma został użyty jako precedens ponad sto lat później przez Sewera z Antiochii z racji zaistniałych podobnych okoliczności. $Z$ treści listu synodalnego z Cezarei wynika, że konflikt został zażegnany zgodnie z życzeniem przesłanym listownie przez ojców synodu w Kapui do Teofila z Aleksandrii i biskupów wschodnich, oraz zgodnie $z$ listem papieża Syrycjusza ${ }^{41}$ : Flawian został ogłoszony jedynym prawnie wybranym biskupem Antiochii. Decyzja została w następstwie zakomunikowana papieżowi Syrycjuszowi ${ }^{42}$.

Tak więc bieg wydarzeń zanotowany przez Sewera z Antiochii zmienia perspektywę spojrzenia na rolę Syrycjusza w sporze antiocheńskim, ukazaną wcześniej przez Ambrożego w liście do biskupa Aleksandrii ${ }^{43}$. Według Francesco Trisoglio rozwiązanie schizmy przez synod w Cezarei Palestyńskiej miało miejsce dzięki wpływowym naciskom papieża Syrycjusza, który nakazał rozwiązanie tego problemu, o czym postanowil w 394 r. synod w Konstantynopo$\mathrm{lu}^{44}$. $\mathrm{Z}$ takiego przebiegu zdarzeń mogłoby wynikać, że papież ten nie pełnił jedynie marginalnej roli $w$ omawianym sporze, ale to jego decyzja wpłynęła znacząco na ich przebieg.

4. Podsumowanie. Zestawienie dwóch wersji biegu wydarzeń, rozgrywających się wokół schizmy antiocheńskiej, domaga się pewnej oceny. Istotne są tu świadectwa, które posiadamy ${ }^{45}$. W przypadku listu Ambrożego do Teofila mamy do czynienia nie tylko ze świadkiem wydarzeń, ale $z$ ich protagonistą. Także drugie świadectwo, list Sewera z Antiochii, nie jest bez wartości. Wiek później, zaświadcza on, że czytał list Syrycjusza, dziś zaginiony, dotyczący rozwiązania konfliktu w Antiochii. Według pierwszego świadectwa Syrycjusz byłby tylko informowany, co do decyzji podjętych pod kierownictwem Ambrożego. Patrząc z kolei na drugie świadectwo można by przyjąć twierdzenie, że Syrycjusz odegrał w konflikcie antiocheńskim decydującą rolę, nakazując biskupom rozwiązanie konfliktu, jako ten, którego „omnium ecclesiarum cura est”. Byłby to cenny dowód, ukazujący decydujący wpływ biskupa Rzymu na przebieg wydarzeń kościelnych na Wschodzie. Z drugiej strony, gdyby nawet przyjąc jedynie pierwsze świadectwo, to i fakt poinformowania Syrycjusza o biegu wydarzeń przez Ambrożego, świadczy nie tylko o kurtuazji względem Syrycjusza, ale i o powadze Piotra, którą uszanował biskup Mediolanu. Niestety, $\mathrm{z}$ braku świadectw, $\mathrm{w}$ tej chwili nie możemy powiedzieć nic pewnego na ten temat. Możemy jedynie przypuszczać, że rola Syrycjusza we wschodniej

\footnotetext{
${ }^{41}$ Por. tamże, s. 285, przypis 1.

42 Por. Festugière, Antioche païenne et chrétienne, dz. cyt., s. 257.

${ }^{43}$ Por. Cavallera, Le schisme d'Antioche (IV $V^{e} V^{e}$ siècle), dz. cyt., s. 286.

44 Por. Trisoglio, Sant'Ambrogio e Massimo il Cinico, art. cyt., s. 792.

$45 \mathrm{~W}$ listach przypisywanych Syrycjuszowi jako autentyczne (pomijając list De Bonoso [= Epistula VIII $]$ jako list Ambrożego), nie ma wzmianki o tym wydarzeniu.
} 
polityce kościelnej nie była jedynie marginalną, co więcej, w zestawieniu $\mathrm{z}$ osobowością Ambrożego, przed którym ugiął się nawet cesarz Teodozjusz, wydaje się, że w czasie pontyfikatu Syrycjusza, świadomość pozycji biskupa Rzymu w całym Kościele, byla już dość wyraźna, co wskazywałoby więc na wzrost znaczenia biskupa Rzymu i jego prymatu w Kościele.

\section{KWESTIA BISKUPA BAGADIUSZA I SYNOD W KONSTANTYNOPOLU (394)}

Decyzja ojców synodalnych z Cezarei nie znalazła przyjęcia na Zachodzie. W 398 r. Flawian nie zostal jeszcze uznany za prawowitego biskupa Antiochii. W międzyczasie umarł Ewagriusz ( $† 394)$, a wraz z nim przyczyna schizmy. Jednakże i te wydarzenia nie przyniosły pokoju w tym regionie kościelnym ${ }^{46}$. W tym samym czasie, w pobliskiej Arabii, stolicy metropolitalnej w Bostrze, dochodziło do pewnych antagonizmów, które wydają się być bardzo żywe, nawet jeżeli nie znamy dostatecznie ich motywów. Oto niektóre fakty: biskupa Bagadiusza potępiono podczas jego nieobecności, a następnie pozbawiono go stolicy biskupiej. Stało się tak za przyczyną dwóch biskupów Cyryla z Jerozolimy i Palladiusza; nowym zaś biskupem ustanowiono Agapiusza. Bagadiusz złożył swój protest podczas synodu w 381 r., w obecności swego rywala. Spór jednak trwał jeszcze przez 10 lat. Dla rozwiązania konfliktu nie zwrócono się do metropolity Antiochii, ani też nie zwołano synodu diecezji wschodnich. Obaj antagoniści zwrócili się z tą sprawą do biskupa Rzymu, który ze swej strony wyznaczył Teofila $z$ Aleksandrii jako arbitra. Ten jednak, jak twierdzą historycy, nie podjął tej sprawy, jak również nie chciał przewodniczyć synodowi w Cezarei w 393 roku ${ }^{47}$. Dlatego też z inicjatywy papieża Syrycjusza, 29 września 394 r., został zwołany synod w Konstantynopolu, aby zbadać konflikt między biskupami Arabii ${ }^{48}$. Obok Nektariusza ( $†$ 398), patriarchy Konstantynopola, byli na nim obecni Teofil z Aleksandrii i Flawian z Antiochii. Ten tzw. synod Rufina zgromadził przedstawicieli najbardziej znamienitych postaci ze wszystkich Kościołów Wschodu ${ }^{49}$. Ojcowie synodalni przypomnieli, że jeden biskup nie może być konsekrowany ani złożony jedynie przez dwóch innych biskupów, a zwłaszcza podczas jego nieobecności. Poza tym zadecydowali, że każde złożenie $z$ urzędu jest nieważne, jeśli nie otrzyma aprobaty synodu i wszystkich biskupów danej prowincji kościelnej. Zgromadzenie to przysłużyło się do ustanowienia pokoju we wschodniej części chrześcijaństwa. Biskupi zebrani w Konstantynopolu wypełnili w ten sposób wolę papieża Syrycjusza,

\footnotetext{
${ }^{46}$ Por. Cavallera, Le schisme d'Antioche ( $I V^{e}-V^{e}$ siècle), dz. cyt., s. 287.

${ }^{47}$ Por. Storia della Chiesa, red. Fliche - Martin, III/2, dz. cyt., s. 666-667; Hefele, Histoire des Conciles, II/1, Paris 1908, 97-99.

48 Por. F. Cavallera, Le schisme d'Antioche ( $I V^{e}-V^{e}$ siècle), dz. cyt., s. 288.

${ }^{49}$ Por. listę obecnych na synodzie: Concilium Costantinopolitanum (393), Mansi III 851-852.
} 
kładąc kres schizmie arabskiej ${ }^{50}$. Ostateczne jednak rozwiązanie schizmy antiocheńskiej i ustalenie pokoju na Wschodzie dokona się cztery lata później, kiedy Jan, kapłan z Antiochii (wierny Flawianowi, jego uczeń) ${ }^{51}$, zostanie wybrany biskupem Konstantynopola, zaaprobowanym przez papieża Syrycju$\mathrm{sza}^{52}$. Imię tego biskupa, znane jest $\mathrm{w}$ historii wraz $\mathrm{z}$ przydomkiem Złotousty. To wydarzenie, relacjonowane przez historyków, ukazuje niewątpliwie ważną rolę papieża Syrycjusza w rozwiązaniu tej kwestii: $\mathrm{z}$ jego inicjatywy zostaje zwołany synod, on zaś zatwierdza jego decyzje.

\section{HEREZJA BONOZJUSZA BISKUPA NAISSY}

Historia Flawiana, któremu Rzym odmówił komunii, podczas gdy biskupi Illyricum go popierali, ukazuje pewną niezależność bałkańskich hierarchów w relacji do Rzymskiej stolicy. Istotnie, kiedy episkopat Macedonii znalazł się w trudnej sytuacji, to szukając pomocy u Kościołów Zachodu zwrócił się do biskupa Mediolanu ${ }^{53}$. Takie zaś postępowanie ma swoje uzasadnienie: według znanych nam faktów, biskup Ambroży cieszył się w pełni swoim autorytetem nie tylko w Kościele Zachodnim, ale także względem cesarza Teodozjusza ${ }^{54}$. Wydaje się to potwierdzać także wydarzenie związane $z$ osobą Bonozjusza.

Bonozjusz, biskup Naissy, został oskarżony o rozpowszechnianie błędnych teorii negujących dziewictwo Maryi ${ }^{55}$. Jego sprawa została poddana rozpatrzeniu w Kapui. Powstaje znów pytanie, kto i dlaczego podporządkował sprawę biskupa Bonozjusza synodowi rzymskiemu w Kapui? Ch. Pietri uważa, że herezja Bonozjusza nie została bezpośrednio podporządkowana osądowi Syrycjusza, ale raczej Ambrożemu ${ }^{56}$. Wydaje się to być potwierdzone również faktem odwołania się Bonozjusza do biskupa Mediolanu, kiedy to według werdyktu z Kapui, jego sprawę mieli rozpatrzyć biskupi Macedonii i pobliskich prowincji ${ }^{57}$. Także zachowanie się biskupów, którzy zostali zobowiązani

\footnotetext{
${ }^{50}$ Por. Storia della Chiesa, red. Fliche - Martin, III/2, dz. cyt., s. 667-668.

51 Jan, który od potomnych otrzymal przydomek Zlotousty, por. A.M. Malingrey, Giovanni Crisostomo, DPAC II 1551-1552.

52 Por. Cavallera, Le schisme d'Antioche (IVe- $V^{e}$ siècle), dz. cyt., s. 289.

53 Por. Pietri, Roma Christiana, t. 2, dz. cyt., s. 1077.

${ }^{54}$ Por. fakt naklonienia cesarza Teodozjusza do publicznej pokuty za rzeź $\mathbf{w}$ Tesalonikach, por. Historia Kościoła, red. J. Daniélou - H.J. Marrou, t. 1: Od początków do roku 600, thum. M. Tarnowska, Warszawa 1986, 246.

${ }_{55}$ Problem osoby Bonozjusza nie zostal jeszcze do tej pory w pelni wyjaśniony. Nie pozostalo po nim żadne pismo. Nasza wiedza o nim pochodzi $z$ innych źródeł, por. G. Bardy, Bonosus, DHGE IX 1096-1097; S.L. Greenslade, The Illyrian Churches and the Vicariate of Thessalonica 378-395, JTS 46 (1945) 27-28.

${ }^{56}$ Por. Pietri, Roma Christiana, dz. cyt., t. 2, s. 1079.

57 Por. Ambrosius, Epistula de Bonoso 2, CSEL 82/3, 8.
} 
do zajęcia się tym problemem, potwierdzałoby hipotezę Ch. Pietri, gdyż i oni zwrócili się do Ambrożego z prośbą o wydanie opinii na temat Bonozjusza ${ }^{58}$. M. Zelzer uważa, że Ambroży odpowiedział metropolicie Macedonii listem, który jest owocem synodu zwołanego przez niego w Mediolanie w 393 roku $^{59}$. Analizując kontekst polityki Ambrożego w tym rejonie kościelnym, wydaje się być łatwe zrozumienie decyzji biskupów Illyricum. Tak więc papież Syrycjusz nie uczestniczyłby bezpośrednio w rozwiązaniu, tym razem kwestii dogmatycznej, powstałej w Kościele wschodnim, jednak, jak podają autorzy II tomu Historii Kościoła, pod kierunkiem H. Jedina, „powierzył sąd nad biskupem z Naissy, który nie uznawał wiecznego dziewictwa Maryi, synodowi w Kapui, któremu przewodniczył Ambroży (391) i biskupom Illyricum"60.

\section{ILLYRICUM - PATRIARCHAT ZACHODNI NA WSCHODZIE}

Podział polityczny Illyricum na część wschodnią i zachodnią ${ }^{61}$, nie był bez znaczenia dla polityki kościelnej biskupa Rzymu. W sposób szczególny zainteresowanie papieży, według tego, co podaje zachowana korespondencja, kon-

${ }^{58}$ Por. tamże 1, CSEL 82/3, 7-8.

59 Por. M. Zelzer, CSEL 82/3, s. XXX-XXXI. Przypominamy, że jeżeli chodzi o przypisanie autorstwa Listu de Bonoso (CSEL 82/3, 7-10) uczeni są jeszcze podzieleni. Jeśli przyjmie się, że jego autorem jest papież Syrycjusz, to zostaje on ukazany on jako promotor prawa: ,il rispetto delle competenze altrui deriva dal suo senso di ordine e dalla sua concezione della chiesa articolata in modo locale, per cui all'autorità suprema del vescovo di Roma spetta il giudizio di appello e la sentenza definitiva in caso di controversie, ma non l'arbitrio di soffocare le legittime espressioni delle autonomie locali che spettano di diritto ai singoli episcopati" (Falbo, Il primato della Chiesa di Roma, dz. cyt., s. 378). Mimo tej tak pozytywnej wypowiedzi na temat Syrycjusza, przychylamy się ku tezie, iż List de Bonoso napisał św. Ambroży z Mediolanu. Fakt ten został gruntownie przeanalizowany, o czym świadczą następujące publikacje: J.A. De Aldama, La carta ambrosiana «De Bonoso», „Marianum” 25 (1963) 1-22; S.M. Meo, La verginità perpetua di Maria nella lettera di papa Siricio al vescovo Anisio di Tessalonica, „Marianum” 25 (1964) 447-469; Ch.W. Neuwmann, The Virgin Mary in the Works of Saint Ambrose, Fribourg 1962; F. Di Capua, Il ritmo prosaico nelle lettere dei papi e nei documenti della cancelleria romana dal IV al XIV secolo, „Lateranum” 3 (1937) 3-275; F. Cavallera, La lettre sur l'évêque Bonose est-elle de saint Sirice ou de saint Ambroise?, BLE 21 (1920) 141-147; C. Silva-Tarouca, Institutiones historiae ecclesiasticae, Romae 1933; P. Coustant, Monitum, PL 13, 1173-1174; C. Baronius, Annales ecclesiastici (388-411), ed. A. Theiner, t. 6, Barrum - Ducum 1866, n. 73; M. Zelzer, CSEL 82/3, Vindobonae 1982, s. XXX-XXXI; G. Bardy, Bonosus, DHGE IX 1096-1097; L. Gambero, La tesi di Bonoso contro la perpetua verginità di Maria e la confutazione di Ambrogio di Milano, w: XVI Centenario del concilio di Capua (392-1992). Atti del Convegno internazionale di studi mariologici (Capua 19-24 maggio 1992), red. G. Liccardo, Capua - Roma 1993, 35-48.

60 Storia della Chiesa, t. 2, dz. cyt, s. 279.

61 Diecezje cywilne Macedonii i Dacji w roku 395 były przyporządkowane Cesarstwu Wschodniemu, por. Greenslade, The Illyrian Churches and the Vicariate of Thessalonica, art. cyt., s. 17-24; L. Duchesne, Histoire ancienne de l'Église, III, Paris 1910, 176-177. 
centrowało się na diecezjach Dacji i Macedonii, które były podporządkowane biskupowi Tesalonik. Wydaje się jednak, że te dwie diecezje cywilne kontynuowały swoją niezależność od jurysdykcji papieskiej, wchodząc w skład cesarstwa wschodniego, którego metropolitą był biskup Konstantynopola. Powstaje w ten sposób tzw. kwestia patriarchatu papieskiego w Tesalonikach, którego rola wyłania się $\mathrm{w}$ sposób bardzo widoczny począwszy od $\mathrm{V}$ wieku. Wobec zaistniałej kwestii należy postawić pytanie, kiedy powstal patriarchat papieski w Tesalonikach i który z papieży dał jej początek ${ }^{62}$.

W jednym ze swoich listów, papież Innocenty I (401-417), pisząc do Anizjusza, biskupa Tesalonik, sugeruje, ze ten wikariat został ustanowiony już w czasach papieży Damazego i Syrycjusza ${ }^{63}$. Także w liście tego samego papieża do następcy Anizjusza na stolicy biskupiej Rufusa, z 412 r., potwierdza władzę, jaką posiadał biskup Tesalonik, według tego, co ustanowili poprzedni papieże ${ }^{64}$. Uczeni badający to zagadnienie dzielą się na dwie grupy: w pierwszej znajdujemy większość historyków, którzy przyjąwszy stwierdzenia Innocentego, przyjmują, że wikariat w Tesalonikach został ustanowiony przez papieża Damazego $^{65}$, czy też przez jego następcę Syrycjusza ${ }^{66}$. Przedstawiciele drugiej grupy nie przyjmują tych świadectw jako wystarczających, aby mówić o ustanowieniu papieskiego wikariatu jurydycznego w Tesalonikach. Wśród nich jest

${ }^{62}$ Takie pytanie postawil J. Macdonald $\mathrm{w}$ artykule zatytułowanym: Who institued the Papal Vicariate of Thessalonica?, StPatr 4 (1961) vol. 2, 478-482.

${ }^{63}$ Por. Innocentius, Epistula „Cum dominus noster” 4, w: Epistularum Romanorum Pontificum ad vicarios per Illyriam aliosque episcopos Collectio Thessalonicensis ad fidem Cod. Vat. Lat. 5751, red. C. Silva Tarouca, Textus et documenta. Series theologica, 23, Roma 1937, 20: „Cui etiam anteriores tanti ac tales viri praedecessores mei episcopi, id est sanctae memoriae Damasus, Siricius atque supra memoratus vir [Anastasius] ita detulerunt, ut omnia quae in illis partibus gererentur, sanctitati tuae quae plena iustitiae est, traderent cognoscenda".

${ }^{64}$ Por. Innocentius I, Epistula „Lectissimo et gloriosissimo Moysi” 5, 22, tamże: „Vere enim eius sacratissimis montis, lectissimae sinceritatis tuae providentiae ac virtutii hanc inungimus sollicitudinem, non primitus haec ita statuentes, sed praecessores meos apostolicos imitati, qui beatisimis Acholio et Anysio inungere pro eorum meritis ista voluerunt".

${ }^{65}$ Por. F.W. Puller, The Primitive Saints and the See of Rome, London 1900, 157; B.J. Kidd, A History of the Church to 461, t. 2, Oxford 1922, 280; J. Barmby, Innocentius, w: Sects and Doctrines, t. 3, New York - Milwood N.Y. 1974, 243-244. Wedlug Grisara „a difendere [...] lo stato giuridico fin allora vigente Damaso o forse il suo successore Siricio stabilì il vicariato apostolico di Tessalonica" (H. Grisar, Storia di Roma e dei Papi nel medio evo esposta secondo le fonti scritte ed $i$ monumenti con particolare riguardo alla civiltà ed all'arte, t. 1: Roma alla fine del mondo antico, Roma 1908, 270).

66 Por. L. Duchesne, Histoire ancienne de l'Église, III, Paris 1910, 179-190: „[...] mais la charge confiée à Acholius [przez Damazego - komentarz autora] n'était peut-être pas définie avec précision, et l'institution vicariale véritable paraît n'avoir commencé qu'avec le successeur de Damase, Sirice, qui, au témoignage de saint Léon, donna à Anysius, lui-même successeur d'Acholius, une délégation précise"; J. Zeiller, Les origines chrétiennes dans les provinces danubiennes de L'Empire romain, Roma 1967, 369; E. Pelekanidou - C. Nardi, Tessalonica. I. Città e cristianesimo, DPAC II 3431. 
S.L. Greenslade, który przypisuje to zadanie papieżowi Anastazemu (399-401) oraz J. Macdonald, który udowadnia, że dopiero począwszy od papieża Innocentego I można mówić o wikariacie papieskim w Tesalonikach ${ }^{67}$.

Według ostatniego autora, który po części zgadza się z argumentami Greenslade'a ${ }^{68}$, wikariat w Illyricum nie został ustanowiony ani przez Damazego, ani przez Syrycjusza. Istotnie, stwierdza on, że pomiędzy listami Damazego, jakie pozostały do naszych czasów, są dwa do Acholiusza, biskupa Tesalonik, w których nie wzmiankuje się o utworzeniu tak ważnego urzędu, ani nie mówi się o jakimkolwiek wikariacie! Papież domaga się jedynie, aby Acholiusz wykorzystał swój wpływ na dworze w Konstantynopolu, aby zapobiec konsekracji biskupiej Egipcjanina Maksyma Cynika ${ }^{69}$.

Podobnie też rzecz się ma z Syrycjuszem, który napisał list do Anizjusza, następcy Acholiusza, nie wypowiadając się na temat wikariatu. Papież prosił go jedynie o to, by czuwał nad zgromadzeniami biskupów w jego rejonie ${ }^{70}$. Jako dowód na poparcie swojej tezy, omawiany autor podaje list dotyczący sprawy Bonozjusza (De Bonoso), przypisywany Ambrożemu, którego treść wskazuje na to, że w $392 \mathrm{r}$. nie istnial zaden wikariat papieski w Tesalonikach, przekazany Anizjuszowi i jego następcom. Takie stwierdzenie usprawiedliwiałoby postępowanie Anizjusza, który zwrócił się o radę nie do Syrycjusza (jako swego bezpośredniego zwierzchnika), ale do biskupa Mediolanu ${ }^{71}$.

Jeśli chodzi o pontyfikat Anastazego (399-401), następcy Syrycjusza, a poprzedzający Innocentego, nie możemy nic powiedzieć $\mathrm{z}$ powodu braku źródeł. Dlatego też należy odrzucić tezę Greenslade'a ${ }^{72}$. Z racji więc faktu, iż nie można ustalić dokładnej daty ustanowienia wikariatu papieskiego w Tesalonikach, który już w następnych wiekach pełnił swą funkcję ${ }^{73}$, możemy jedynie zadowolić się pewnymi hipotezami:

- po pierwsze jest faktem niezaprzeczalnym, że świadomość istnienia specjalnej władzy udzielonej Acholiuszowi i Anizjuszowi, wyrażona przez papieża Innocentego I, świadczy o tym, że taka władza w jakiś sposób została udzielona biskupom Tesalonik, przez jego poprzedników; tym niemniej prawdą jest, że

${ }^{67}$ Por. MacDonald, Who institued the Papal Vicariate of Thessalonica?, art. cyt., s. 481-482.

68 Por. Greenslade, The Illyrian Churches and the Vicariate of Thessalonica 378-395, art. cyt., s. $25-27$.

${ }^{69}$ Por. Damasius, Epistolae V-VI: „Decursis litteris”, „Ad meritum”, PL 13, 365-370.

${ }^{70}$ Por. J. MacDonald, art. cyt., s. 479.

71 Por. Epistula de Bonoso (Epist. 71; Maur. 56a) 1, CSEL 82/3, 7; zob. Macdonald, art. cyt, s. 479.

72 Por. MacDonald, tamze: „But although going thus with Dr. Greenslade, I canot agree with him that the vicariate may have been initiated by Anastasius".

${ }^{73}$ Można wspomnieć o odwołaniu się biskupa Konstantynopola Epifaniusza, który złożył $\mathrm{z}$ urzędu Stefana, biskupa Larysy w Tesalonikach, z racji jego niekanonicznej konsekracji. Pozbawiony z urzędu Stefan zwrócil się bezpośrednio do Rzymu, do papieża Bonifacego II, uznając w ten sposób jego prymat nad Kościołem w Tesalonikach, por. Macdonald, art. cyt., s. 479 i 481. 
dopiero wraz z tym papieżem można mówić o właściwym wikariacie papieskim w Tesalonikach;

- odnośnie do omawianej kwestii istnieje pewna trudność, mianowicie nie posiadamy wszystkich dokumentów papieży Damazego, Syrycjusza, czy Anastazego. Hipotetycznie więc można przypuszczać, że każdy z nich mógł dać początek takiemu wikariatowi na mocy dekretału, który dzisiaj nie istnieje. Jednak trzeba zaznaczyć, że jeśli chodzi o region Bałkanów, posiadamy bardzo ważny zbiór dokumentów, zwany Collectio Thessalonicense, zawierający korespondencje papieży $\mathrm{z}$ hierarchami Tesalonik. Tak więc gdyby istniały jakieś odnośne dokumenty dotyczące tego regionu kościelnego z pewnością znalazłyby się w tej kolekcji.

- w przypadku listów papieży z IV wieku, tj. z okresu, w którym budzi się i manifestuje świadomość prymatu biskupa Rzymu, wydaje się niemożliwe, aby jakiś dekretał papieski, który miałby tak wielkie znaczenie dla takiego wydarzenia i jednocześnie posiadający wymiar powszechny, nie został umieszczony i w ten sposób zachowany w jednym ze zbiorów oficjalnych dokumentów Kościoła, takich jak np. Kolekcja Dionizego Matego.

Mając na uwadze powyższe rozważania podsumujmy omawianą kwestię w zgodzie $\mathrm{z}$ historykami ${ }^{74}$, że odnośnie do ustanowienia wikariatu papieskiego na Wschodzie trzeba raczej mówić o procesie ewolutywnym. Prawdopodobnie początek został nadany przez Damazego, który ustanowił biskupem Acholiusza. Syrycjusz kontynuował politykę swego poprzednika powierzając Anizjuszowi kontrolę nad ustanawianiem biskupów w Illyricum ${ }^{75}$. Te posunięcia byłyby jedynie preludium do owego procesu, który swoje formalne zwieńczenie $\mathrm{w}$ postaci wikariatu papieskiego $\mathrm{w}$ Tesalonikach otrzyma za papieża Innocentego $\mathrm{I}^{76}$.

IV wiek był z punktu widzenia doktrynalnego i dyscyplinarnego czasem systematyzacji w Kościele (dwa sobory ekumeniczne i ponad 180 synodów jak podaje Alberigo - jakie odbyły się w tym wieku). Listy Syrycjusza, które przede wszystkim zajmują się problemami dyscyplinarnymi, dotyczącymi różnych dziedzin chrześcijańskiego życia, świadczą o wkładzie, jaki wniósł ten

${ }^{74}$ Por. Storia della Chiesa, t. 2, dz. cyt., s. 279; Pelekanidou - Nardi, Tessalonica, art. cyt., s. 3431 .

75 W studium na temat prowincji wschodnich cesarstwa rzymskiego Onorato Bucci, wzmiankując o podzielonym posłuszeństwie tego regionu względem stolicy w Rzymie i w Konstantynopolu stwierdza, że „Papa Siricio affidò al vescovo di Tessalonica Anisio funzioni di suo vicario”, jednak bez podania jakiegokolwiek potwierdzającego argumentu, por. O. Bucci, Le provincie orientali dell'impero romano. Una introduzione storico-giluridica, Roma 1998, 148.

${ }^{76}$ Por. Falbo, Il primato della Chiesa di Roma, dz. cyt., s. 379. 
papież do uporządkowania dyscypliny kościelnej. Charakterystyczną cechą tego pontyfikatu jest wzrastająca świadomość znaczenia Stolicy Piotrowej w Kościele Zachodnim oraz żywe zainteresowanie się problemami Kościołów wschodnich.

K.B. Osborn, analizując relację między biskupami Kościołów lokalnych, a biskupem Rzymu, zauważa, że tylko niektórzy papieże wypełniając posługę biskupa Rzymu, sprawowali ją mocą udzielonego im autorytetu. Gdy chodzi - Syrycjusza, uwidacznia się fakt jego przynależności do tych rzymskich pontyfików, którzy realizowali swoją posługę mocą i świadomością władzy prymatu $^{77}$.

Krótkie studium tego pontyfikatu w relacji do chrześcijańskiego Wschodu, które zawarliśmy w niniejszym artykule, ukazało coraz bardziej dochodzącą do głosu i liczącą się w całym Kościele postać biskupa Rzymu przy końcu złotego wieku patrystyki. Na podstawie dokumentów oraz ukazanych wydarzeń $\mathrm{z}$ historii Kościoła, znaczenie pontyfikatu Syrycjusza jawi się nie tyle jako owoc jego osobistego autorytetu ${ }^{78}$, ile raczej jest wyrazem dojrzewającej świadomości znaczenia roli biskupa rzymskiego, którego autorytet sięga czasów ustanowienia Kościoła w Rzymie przez Apostoła Piotra. Ta świadomość stale wzrastała i znajdowała swój wyraz w dokumentach synodalnych oraz działalności biskupów Wiecznego Miasta, szczególnie Damazego, a także jego bezpośredniego następcy ${ }^{79}$. $Z$ cała pewnością możemy więc stwierdzić, że papież Syrycjusz był świadomym nosicielem i wyrazicielem idei prymatu, co ukazał w swoich dekretałach, adresowanych do biskupów łacińskich ${ }^{80}$, jak również, prowadząc politykę kościelną względem chrześcijańskiego Wschodu w czasach swego pontyfikatu.

${ }^{77}$ Por. K.B. Osborne, Priesthood. A History of Ordained Ministry in the Roman Catholic Church, New York - Mahwah 1989, 145.

${ }^{78}$ Badacz starożytnego papiestwa E. Caspar wypowiada się niezbyt chlubnie o osobowości Syrycjusza, przyznaje mu jednak tytuł „nosiciela Tradycji”: „Siricius war, ohne persönlich hervorzutragen, solch ein Träger der Tradizion" (E. Caspar, Geschichte des Papsttums von den Anfängen bis zur höhe der Weltherschaft, Bd. 1, Tübingen 1930, 266-267).

${ }^{79}$ Por. Concilium Sardicense, can 3, Mansi III 7-8: „[...] Petri apostoli memoriam honoremus [...]”. Kanon synodu z Sardyki nazywa stolicę rzymską „caput” całego Kościoła. W ten sposób potwierdza wyraźnie jurysdykcję biskupa Rzymu nad wszystkimi Kościołami, por. O. Marucchi, Il pontificato del papa Damaso e la storia della sua famiglia secondo le recenti scoperte archeologiche, Roma 1905, 28.

${ }^{80}$ Por. J. Woch, Autorytet Stolicy Apostolskiej za pontyfikatu Syrycjusza, biskupa Rzymu w latach 384-399, SACh 17 (2004) 130-144. 


\section{IL VESCOVO DI ROMA DI FRONTE AI PROBLEMI DELLE CHIESE ORIENTALI ALLA FINE DEL IV SECOLO}

\section{(Riassunto)}

Lo studio presentato in questo articolo cerca di studiare, alla base dei documenti, in quale maniera è stato realizzato il mandato petrino: „pasce oves meas", alla fine del IV secolo. Nel modo particolare fu esaminato il pontificato di papa Siricio (384399), specie sotto l'aspetto del suo rapporto verso le Chiese d'Oriente. Dallo studio emerge che questo vescovo di Roma era cosciente dell'incarico intrapreso, ,per Dei gratiam", di avere cura per tutte le Chiese. In modo particolare è stata analizzata la cosiddetta questione antiochena, la causa del vescovo Bonoso, del vescovo Bagadio, nonché il problema dell'istituzione del patriarcato occidentale in Oriente (Illirico). In tutti questi casi Siricio si dimostra come responsabile per la pace ed unità della Chiesa, impegnandosi sia in persona che attraverso i suoi legati. 